\title{
Focus
}

\section{Gereformeerde theologie in wereldwijd perspectief}

\author{
R.T. te Velde
}

Michael Allen en Scott R. Swain (red.), The Oxford Handbook of Reformed

Theology (Oxford: Oxford University Press, 2020) 663 p., € 127,29 (ISBN:

9780198723912).

Wat is gereformeerd? In Nederland, dat als weinig andere naties door de gereformeerde tak van de Reformatie van de 16de eeuw is gestempeld, kunnen we die vraag in uitputtend detail bespreken. Wie in een van de vele gereformeerde of hervormde kerken is opgegroeid, is vertrouwd met de gereformeerde overtuiging die in geloofsleer, spiritualiteit, kerkelijk leven en maatschappelijke betrokkenheid heeft vorm gekregen. Deze diepe verworteling in de gereformeerde traditie is een groot goed. Tegelijk kan er een zekere vertekening van het beeld door ontstaan. Het gereformeerde is ons zozeer vanzelfsprekend geworden, dat we minder in staat zijn om de motieven en de vraagstukken achter de gereformeerde geloofsleer en geloofsbeleving te ontdekken, en daardoor ook moeilijker tot een eigentijdse en vruchtbare voortzetting van deze traditie komen. Een tweede nadeel is dat we zo getraind zijn om te letten op de verschillen en variaties binnen de gereformeerde gezindte, dat we het gemeenschappelijke in verband met de wereldwijde kerk van Christus uit het oog verliezen.

Die verbinding van het 'gereformeerde' met het 'katholieke' is wat de redacteuren van het Oxford Handbook of Reformed Theology nadrukkelijk op het oog hebben. Michael Allen en Scott Swain zijn beiden verbonden aan het Reformed Theological Seminary in Orlando, Florida. In eerdere publicaties maakten zij zich sterk voor een herontdekking van de gereformeerde 'roots', niet alleen in het werk van reformatoren als Calvijn, Bullinger en Bucer, maar ook in de voorafgaande theologie van kerkvaders en middeleeuwse denkers en in de scholastiek-gereformeerde uitwerking van de generaties na Calvijn. Door deze historische verbreding van het beeld komt als vanzelf het 'katholieke' gehalte van gereformeerde theologie naar voren: deze is geen specialité de la maison, maar consequente en toegespitste uiting van het geloof van de kerk van alle tijden en alle plaatsen. 
Doelstelling van de Oxford Handbooks is om de stand van zaken op een onderzoeksterrein weer te geven en tegelijk een voorproef te bieden van vernieuwende inzichten en ontwikkelingen. Dit overzicht van gereformeerde theologie, waaraan een kleine veertig vertegenwoordigers van de brede gereformeerde traditie meewerkten, slaagt daar uitstekend in. Het lijvige boek is in drie rubrieken onderverdeeld: contexten, teksten en thema's. Uit elk van deze drie breng ik iets naar voren.

Het eerste deel, dat gereformeerde theologie belicht vanuit een aantal contexten waarin zij werd of wordt beoefend, trof mij bij eerste oogopslag als een originele en veelbelovende keus van de redacteuren. De laatste decennia is immers de verwevenheid van theologische kennis met tijd en omstandigheden sterker naar voren gekomen. Dat maakt nieuwsgierig: gereformeerde theologie heeft soms het imago van eenduidige tijdloosheid, een geloofsovertuiging die wel in beton gegoten lijkt. Ligt dat misschien toch genuanceerder? En welk zicht biedt het contextuele karakter van gereformeerde theologie op haar katholieke gehalte? Wanneer contextuele theologie zich niet verliest in aanpassing, maar in een actieve uitwisseling haar eigenheid met vraagstukken en omstandigheden van een bepaalde tijd en plaats weet te verbinden, kan juist daarin een vernieuwend appèl op de kerk van alle tijden en plaatsen worden gedaan.

Onder het kopje 'Contexten' komt zowel historische als geografische verscheidenheid naar voren. De eerste twee bijdragen, door Aza Goudriaan en Christopher Cleveland, belichten de doorwerking van kerkvaders en middeleeuwse theologen. In theologiehistorisch onderzoek van de laatste dertig, veertig jaar is duidelijk geworden dat de Reformatie van de 16de eeuw niet een volstrekt nieuw begin is, maar met duizend draden verbonden is aan de voorafgaande eeuwen. In de gangbare beeldvorming blijft echter met name de 'scholastiek' van de Middeleeuwen een verdachte factor. Op basis van een inmiddels flink gegroeide traditie van herwaardering van postreformatorische theologie laat Cleveland zien dat van onkritische overname of massieve verwerping van scholastieke begrippen en argumenten geen sprake is. Theologen als Girolamo Zanchi, Gisbertus Voetius en Francesco Turrettini maakten een doelbewuste selectie van methoden en inzichten die door de traditie werden aangereikt, en zetten die in voor de uitleg en verdediging van het gereformeerde geloof in allerlei nieuwe discussies rond bijvoorbeeld de vrije wil en de godheid van Christus.

Een hoogtepunt in het eerste deel van het Handbook is het hoofdstuk over gereformeerde theologie en de Verlichting door David Sytsma. Naar twee kanten toe is de verhouding tussen gereformeerde theologie en de filosofie van de Verlichting een spannende. In de eerste plaats werd in de 20ste eeuw 
door velen gesuggereerd dat de rationele inslag van gereformeerde theologen voorbereidend werkte voor het latere rationalisme dat grote delen van het christelijk geloof overboord zette. In de tweede plaats leeft sinds de 19de eeuw breed het gevoel dat 'na de Verlichting' de theologie niet op de oude voet voort kan, maar zich door de filosofische kritiek moet laten corrigeren. Sytsma laat zien in hoeveel verschillende debatten gereformeerde theologen op filosofische uitdagingen ingingen. Er is niet één verhaal van 'de theologie' en 'de Verlichting', maar er zijn meerdere verhalen van afwijzing, confrontatie, overname en aanpassing. Zeker in de 17 de eeuw maken theologen als Voetius, Witsius en Leydecker volop deel uit van de academische wereld, en is het geen uitgemaakte zaak dat nieuwe filosofieën als die van René Descartes en Baruch de Spinoza de overhand krijgen ten koste van de aristotelische filosofie waarmee de gereformeerde theologen zijn grootgebracht. In de filosofische discussies lopen ook theologische twistpunten en scheidslijnen mee: in Engeland, bijvoorbeeld, zijn sympathisanten van de Verlichting vaak ook gecharmeerd van arminiaanse of sociniaanse denkbeelden inzake de leer van de verlossing. Sytsma wijst in dat verband op het latitudinarisme dat zich in de 18de eeuw breed maakte, en dat een deïstische visie op Gods bestuur van de wereld combineerde met een versie van de christelijke geloofsleer waarvan de scherpe 'scholastieke' kantjes waren afgeslepen.

Het is boeiend om de lotgevallen van de gereformeerde theologie in verschillende periodes van de geschiedenis te vernemen. Daarnaast komt ook de geografische verscheidenheid aan bod in drie hoofdstukken over Europa, Noord-Amerika en Korea en Zuid-Afrika. Het hoofdstuk over Europa werd geschreven door James Eglinton, docent in Edinburgh en succesvol leider van een 'Bavinck-school' die de afgelopen jaren een flink aantal dissertaties over deze vooraanstaande Nederlandse neo-calvinist heeft opgeleverd. In kort bestek weet Eglinton het eigene van gereformeerde theologie in de verschillende delen van Europa in de voorbije twee eeuwen goed te typeren, waarbij hij aandacht besteedt aan de algemene politieke en culturele geschiedenis, en naast de bekende namen ook minder bekende representanten van de gereformeerde theologie ten tonele voert. Behalve de bekende gereformeerde kernlanden Schotland, Nederland, Zwitserland, Duitsland en Frankrijk komt terecht ook de geschiedenis van gereformeerde theologie en kerk in Hongarije ter sprake. Het hoofdstuk over 'wereldwijd christendom' (Global Christianity) is wat mij betreft te beperkt. De auteur, D.G. Hart, concentreert zich op Zuid-Afrika en Korea. Binnen de 'gereformeerde oecumene' zijn dit vertrouwde streken. Bij de gereformeerde kerken in Zuid-Afrika gaat het grotendeels om emigranten met een Nederlandse achtergrond, wier lotgevallen bepaald zijn door de Boerenoorlogen, de decennia met het apartheidsbeleid van de Nationale Partij, 
en de omvorming naar een 'zwarte' meerderheidsstaat onder leiding van het Afrikaans Nationaal Congres. Voor Korea ontbreekt een demografische verbinding met het 'oude' Europa, maar daar staat tegenover dat de gereformeerde (presbyteriaanse) kerken sterk beïnvloed zijn door Amerikaanse vormen van theologie en kerk-zijn. Het boeiende is dat in meerdere Aziatische en Afrikaanse landen de theologie zich in hoog tempo aan het ontwikkelen is van vooral ontvangen en reproduceren naar het produceren van theologie 'van eigen bodem'. Dit roept uiteraard vragen op als het gaat om de klassieke dogma's rond de leer van de Drie-eenheid, de Persoon van Christus, en de aard van de verlossing. Contextuele, 'inheemse' theologie bleek nogal eens de neiging te hebben om de continuiteit met religieus en cultureel gedachtengoed uit de vóórchristelijke tijd te benadrukken, met een zeker risico op syncretisme. Toch is de groei naar een zelfstandige en volwaardige eigen vorm van gereformeerde theologie, toegesneden op de verschillende regio's in Azië, Afrika en Zuid-Amerika, toe te juichen. Dat deze ontwikkeling in het Handbook niet in beeld komt, is een gemiste kans, die in een volgende editie zeker rechtgezet moet worden.

Het tweede deel van het Handbook is gewijd aan een selectie van klassieke teksten die het eigene van gereformeerde theologie in verschillende periodes en situaties tot uitdrukking brengen. Voor de experts die gevraagd zijn om een kortere of langere tekst toe te lichten, is het een mooie gelegenheid om de brede en diepe kennis die ze hebben verworven in te zetten als compacte leeswijzer. Zo krijgen we van de Amerikaanse geleerden Donald Sinnema en Lyle Bierma een fraaie introductie op de Drie Formulieren van Eenheid.

Naast de bekende Institutie van Calvijn komen ook de minder bekende Decades van de Zürichse reformator Heinrich Bullinger aan bod. In Nederland was deze collectie van vijftig preken rond de verschillende geloofsthema's bekend onder de titel Huysboeck. Hoewel het wat onder de radar van de 'officiële' theologie bleef, heeft dit meer populaire en praktischgerichte werk vermoedelijk een flinke invloed uitgeoefend op de vorming van de geloofsbeleving van gereformeerden in Nederland en elders. De toelichting door Bruce Gordon maakt duidelijk dat Bullinger de diepere geloofsvragen niet ontwijkt, maar ze altijd behandelt op een manier die aan geloofsopbouw en vertroosting bijdraagt. Opmerkelijk is dat Bullinger in zijn spreken over de sacramenten doop en avondmaal een nauwe koppeling aanbrengt tussen het uiterlijke teken en de innerlijke werking door de Heilige Geest die aan die tekenen verbonden is. Vaak wordt gedacht dat Bullinger, als leerling en opvolger van Huldrych Zwingli, slechts met enige tegenzin zich liet bewegen tot de overeenstemming met Johannes Calvijn over de avondmaalsleer in de Consensus Tigurinus van 1549. Uit de Decades blijkt echter dat hij zelf ook in de klassieke 
augustijnse lijn over 'teken' en 'betekende zaak' dacht. Ten slotte is te noemen dat een deel van de gebundelde preken door Bullinger werd opgedragen aan de Engelse koning Edward VI, die als tienjarige zoon van Hendrik VIII in 1547 de Engelse troon besteeg en al in 1553 overleed, om opgevolgd te worden door zijn rooms-katholieke zuster 'Bloody Mary'. Bullinger is een van de vooraanstaande gereformeerde theologen die poogden om tijdens Edwards bewind de Engelse reformatie bij te sturen en daarvoor een uitgebreid netwerk van correspondentie en publicaties inzetten.

In dit politieke aspect van het gereformeerde denken raakt Bullingers werk aan het geschrift De regno Christi van zijn oudere tijdgenoot Martin Bucer, waarmee het tweede hoofddeel van het Handbook opent. Ook Bucer combineerde diepgravende schriftuitleg en doordenking van de geloofsleer met een praktische, organisatorische en bij tijden politieke inzet voor de daadwerkelijke doorvoering van de kerkhervorming op alle terreinen van het leven. De laatste twee jaren van zijn leven (1549-1551) bracht hij door in het Engeland van Edward VI, waar hij op verzoek van Thomas Cranmer hielp bij de verdere hervorming van de Church of England.

De betrokkenheid van deskundigen bij de door hen gepresenteerde geschriften heeft soms als nadeel dat men de auteur en zijn theologische visie in bescherming neemt. Dit valt bijvoorbeeld op bij de bespreking door Shelli M. Poe van Der christliche Glaube van Friedrich Schleiermacher. Dat Schleiermacher een stevig stempel drukte op de gereformeerde theologie in de 19 de en 20ste eeuw, valt niet te ontkennen. Het is ook zeker zijn verdienste dat hij de grote vraagstukken die vanuit de verlichtingsfilosofie van Kant en anderen aan geloof en theologie werden voorgelegd van een serieuze doordenking heeft voorzien. Daarbij voerde hij een grondige herziening van de christelijke leer door vanuit zijn grondovertuiging dat religie bestaat in het besef van volstrekte afhankelijkheid. Terecht betoogt Poe dat Schleiermachers Anliegen spoort met de gereformeerde intentie om de hele wereld als werkplaats van Gods handelen te beschouwen en daarom de geloofsleer in verband met de hele werkelijkheid te ontwikkelen. Het lijkt me echter dat zij te positief oordeelt over Schleiermachers herziening van fundamentele leerstukken zoals de Drie-eenheid en de Persoon van Christus. Wanneer Schleiermacher weigert om in de zin van de klassieke 'immanente' triniteitsleer te spreken van drie goddelijke Personen, die door hun 'onmededeelbare eigenschappen' (art. $8 \mathrm{NGB}$ ) zijn onderscheiden, en in plaats daarvan in de drie Personen de drievoudige werkzaamheid in schepping, verlossing en kerk van het ene goddelijk Wezen ziet, dan is dit moeilijk als uitdrukking van het gereformeerde geloofsverstaan te typeren.

Naast Schleiermacher is ook Karl Barth een opvallende verschijning, met 
name in de hoofdstukken uit de derde afdeling van het Handbook, die aan de verschillende thema's van de gereformeerde theologie zijn gewijd. Blijkbaar hebben de redacteuren aan de scribenten gevraagd om de actuele doorwerking van de gereformeerde leer aan het hand van het opmerkelijke duo Schleiermacher-Barth te presenteren.

Soms levert dit mooie resultaten op. Barths invloedrijke vernieuwing van de leer van de uitverkiezing komt verschillende keren naar voren. In het hoofdstuk over Gods besluit geeft Paul T. Nimmo (Aberdeen) niet alleen de hoofdpunten van Barths verkiezingsleer kort en helder weer, maar ontleent hij er ook boeiende lessen voor een evenwichtige predestinatieleer aan. Eenzelfde beweging maakt Ivor J. Davidson (Aberdeen, voorheen Otago en St. Andrews) in het hoofdstuk over de Persoon van Christus, dat zeer inhoudrijk en goedgedocumenteerd is. De dynamisering van de tweenaturenleer met behulp van de twee 'staten' (vernedering en verhoging) en de drie 'ambten' (profeet, priester, koning) die Barth in het grote vierde deel van zijn Kirchliche Dogmatik doorvoerde, heet bij Davidson enerzijds een uitwerking van 'krachtige gereformeerde instincten'. Anderzijds waarschuwt hij tegen een toepassing van Barths inzichten die zozeer de 'vernedering' en de 'menselijkheid' in God zelf plaatsen, dat er van een eeuwige godheid van de Middelaar voorafgaand aan de incarnatie geen plaats meer is. Van de 'zelfontlediging' (kenosis) van Christus die Paulus in Filippenzen 2 bezingt, kan dan ironisch genoeg geen sprake meer zijn.

Een minder sterk voorbeeld van invloed van Barth op gereformeerde theologie in de $20^{\text {ste }}$ eeuw betreft de leer van de sacramenten. Niet alleen wilde Barth van het traditionele begrip 'sacrament' afscheid nemen omdat hij het alleen op de menswording van Christus van toepassing achtte, ook kwam hij vanuit een sterk accent op het vernieuwingskarakter van de doop tot een verwerping van de kinderdoop. Martha Moore-Keish besteedt terecht royale aandacht aan het tegengeluid dat door onder anderen de Schotse barthiaan T.F. Torrance stem kreeg. De gereformeerde sacramentsleer is te rijk om aan een geforceerde scheiding tussen 'water' en 'Geest' op te offeren.

Zelfs een uitgebreide recensie kan aan de veelzijdige inhoud van dit Handbook geen recht doen. Het beeld dat van gereformeerde theologie met haar kenmerkende thema's en gezichtsbepalende figuren wordt gegeven is vaak vertrouwd, soms verrassend, en vrijwel altijd verdiepend. Voor een antwoord op de vraag 'Wat is gereformeerd?' worden veel aanzetten gegeven. De slotbeschouwing door redacteur Michael Allen houdt zich begrijpelijkerwijs wat op de vlakte. De veelheid aan accenten en perspectieven binnen de ene gereformeerde familie van theologie laat geen eenduidige conclusies toe. Het is te hopen dat het materiaal dat in dit fraaie overzichtswerk bijeengebracht is 
aanleiding mag zijn om met gegronde overtuiging en in hoopvolle openheid verder te werken aan een gewortelde, vitale en actuele gereformeerde theologie. Laat ik ter afsluiting drie wensen mogen noemen die voorbij de stand van zaken in het Handbook voeren. Vanuit de Nederlandse situatie valt op - hoewel Nederland direct en indirect goed vertegenwoordigd is onder de scribenten - dat de bevindelijk-gereformeerde traditie met haar nadruk op genade en wedergeboorte weinig stem krijgt. Met alle eenzijdigheid die daarin dreigt meen ik toch dat dit een wezenlijk bestanddeel van gereformeerde theologie is. In de tweede plaats zou nadrukkelijker het gesprek tussen gereformeerde theologie en andere tradities en stromingen gezocht mogen worden, waarbij ik met name wijs op de toenemende invloed van charismatische spiritualiteit op vanouds gereformeerde kerken. De zojuist genoemde bevindelijk-gereformeerde lijn heeft voor de bezinning op de Heilige Geest en zijn werk veel in huis. In de derde plaats zie ik graag de toenemende zelfstandigheid van gereformeerde theologen in de 'Majority World' (Azië, Afrika, Latijns-Amerika) meer in beeld komen. De tijd van exporttheologie is voorbij, we zien een wederkerigheid en wisselwerking ontstaan tussen theologie uit alle windstreken, die nog veel open eindjes bevat, maar die tegelijk op een nieuwe manier het katholieke karakter van gereformeerde theologie handen en voeten geeft. 